\title{
Critical Evaluation for Alternative Causes of Drug Induced and Herbal Induced (DILI/HILI) Hepatotoxicity
}

\author{
Vasilios Frankos', Raushanah Najeeullah ${ }^{2}$, Joel Morgan ${ }^{3}$ \\ ${ }^{1}$ Global Regulatory Compliance and Product Safety, Herbalife International of America Inc., Torrance, CA, USA \\ ${ }^{2}$ Post Market Medical Surveillance, Global Post-Market Safety Surveillance, Herbalife International of America \\ Inc., Torrance, CA, USA \\ ${ }^{3}$ Global Post-Market Safety Surveillance, Herbalife International of America Inc., Torrance, CA, USA \\ Email: raushanahn@herbalife.com
}

Received 30 April 2016; accepted 6 June 2016; published 9 June 2016

Copyright (C) 2016 by authors and Scientific Research Publishing Inc.

This work is licensed under the Creative Commons Attribution International License (CC BY).

http://creativecommons.org/licenses/by/4.0/

(c) (i) Open Access

\begin{abstract}
The objective of this review is to highlight the continued exclusion of discussion in the literature regarding alternative causes and proper causality assessment of cases of hepatotoxicity when use of dietary supplements is reported. Though independent experts are working diligently to advance the discussion related to alternative causes of hepatotoxicity resulting in idiosyncratic druginduced liver injury/herb-induced liver injury (DILI/HILI), the literature continues to recite the same cases, such as those presented here, to reiterate potentially biased positions and ignore current, standardized and valid evaluations utilizing the Roussel Uclaf Causality Assessment Method (RUCAM). Several historical cases purporting hepatotoxicity induced by use of dietary supplements are presented in this review to demonstrate how such cases may be improperly assessed due to bias, inconsistent use of causality assessment methods, as well as use of causality assessment methods deemed obsolete. This in essence, delays any true progress in establishing sound criteria to determine and address the actual cause(s) of DILI/HILI.
\end{abstract}

\section{Keywords}

Drug-Induced Liver Injury, RUCAM, Herb-Induced Liver Injury, Causality, Dietary Supplement

\section{Introduction}

Dietary supplements (DS) are an ever growing sector of healthcare, along with lifestyle and wellness trends, 
particularly when it comes to weight loss. There is an abundance of information available regarding proposed links between the consumption of DS in general and some specific nutraceutical brands in the development of (DILI/HILI) in patients who take these products. Unfortunately, in the majority of published cases determined to have been caused by DS consumption, alternative causes for the hepatotoxic events were not considered. As a result, there is now a growing trend to reevaluate these reported cases for alternative causes using the more consistent and objective RUCAM causality assessment method in order to determine the actual causative risk factor(s) for the development of DILI/HILI [1]-[4] though it continues to be largely ignored in the literature.

Many individuals who choose to use DS for weight loss are overweight, some significantly so (Body Mass Index (BMI) > 35). It is important to acknowledge that consumers of DS (particularly weight loss supplementation) include a large number of individuals seeking ways to adopt a healthier lifestyle to reverse or negate issues related to being overweight. It is well-known that metabolic compromise and other chronic conditions are not uncommon to these populations and as a result, may render such individuals more susceptible to liver-related complications especially as they pursue weight loss goals and/or make significant changes to their dietary intake. Pre-existing medical conditions such as obesity, insulin resistance and diabetes can be associated with hepatic steatosis and non-alcoholic fatty liver disease (NAFLD). These are disorders which may return certain types of abnormal serology results. In fact, while weight loss can be a necessary component for disease management [5]-[7], there are health risks associated with any weight loss regimen including lipotoxicity or gall stone formation from rapid weight loss [8]-[10] which can lead to a case of liver injury being diagnosed as DILI/HILI where DS consumption was reported.

In addition, it is possible for an individual to have an individualized immune reaction to a product, the same way one might have an allergic reaction to any food product, such as gluten for example [11]-[13]. This is also discussed in a recent publication which states: “...information collected and described in the literature does not allow speculation about the existence of sensitization in part of the population" [4]. Therefore, the original abnormal serology results and those associated with reexposure that have been reported in the literature may not have been instigated by the consumption of the reported DS, but rather the secondary outcome of a pre-existing medical condition.

As noted in the aforementioned recent publication, an observed issue with some of the reported cases of hepatotoxicity determined to be caused by DS consumption entails insufficient information related to: "patients' history, concomitant use of medication and/or other compounds (including alcohol), observations on discontinuation of use (dechallenge), results found with markers, viral serology and autoantibodies, observations concerning re-exposure to the suspect products, and specifications of product use" [4]. From a clinical perspective this is concerning. Incomplete case evaluations, with no acknowledgement, much less evaluation of preexisting and pertinent risk factors may, at best, bias but also potentially hinder the clinician's efforts to accurately determine the actual causes of hepatotoxicity when consumption of DS are a piece of the patient presentation.

Some of the current issues plaguing meaningful discussion around DILI/HILI and the use of DS include: lack of discussion of alternative causes of hepatotoxicity including liver injury linked to rapid weight loss; preexisting health conditions such as obesity, insulin resistance, diabetes, hepatic steatosis and non-alcoholic fatty liver disease (NAFLD) [14]-[19] (see Table 1); disregard of the reassessment of retrospective cases originally concluded to have been caused by consumption of DS but later determined, by independent experts, to have likely been caused by other preexisting medical conditions, use of known hepatotoxic medications, and other factors; and the implication of a DS brand name as if it constituted a single drug, supplement or herb instead of identifying a single DS product or ingredient sold under a particular brand name.

Observation of the published literature highlights a disconnect between the continued efforts to address the

Table 1. Risk factors for the development of DILI/HILI.

Obesity (BMI $\geq 30)[14]$

Insulin resistance/metabolic syndrome [14]

Diabetes mellitus type II [14]
Hepatic steatosis [16]

Non-alcoholic fatty liver disease (NAFLD) [16]

Hepatic viral infection [17] [18] 
aforementioned issues in the literature, resulting in the perpetual discussion of the same retrospective cases implicating DS consumption as causative [20]-[23] without regard for the reevaluation of these cases by international experts in hepatotoxicity causation nor consideration for other possible factors that may contribute to DILI/HILI. It is of additional concern that authors of some of the more recent publications around DS use and hepatotoxicity are aware of the discussion of alternative causes and related matters [1]-[3] but continue to choose not to include the information in the progression of the knowledge base in published articles and professional conferences.

Since in the majority of the published retrospective cases alternative causes were never considered and subsequently not addressed, it stands to chance that exposure to any number of agents, DS or otherwise, may exacerbate an already compromised liver. Table 2 presents a representative sample of published cases reporting positive DS reexposure tests (some determined with subjective, outdated and/or debunked causality assessment criteria methods) later determined by independent experts to have possible alternative causes.

In the majority of the cases listed in the table, pertinent information such as liver function test values, viral serology or supportive data for assigning causality to DS use were not reported. In the original reports, factors that are known to contribute to the development of liver injury (e.g. BMI of 25 and greater, pre-existing metabolic, cardiovascular and/or hepatic disease, use of hepatotoxic agents, etc.) were not even considered as causative in the reported events. If these important parameters were taken into consideration at presentation, a more plausible cause for the reported injury would have likely have been determined even in the face of reported positive reexposure tests.

Independent medical experts have questioned the methodology by which these cases were evaluated [1]-[4]. In many instances, these same experts are assigning weaker causality outcomes than were previously determined or completely excluded the use of DS as causative. Certain events also appear to have been more likely associated with pre-existing etiologies amongst these cases (e.g. use of known hepatotoxic medications, viral hepatitis, and alcoholism) [2] [3].

Lack of consideration for alternative causes of hepatic injury is not the only issue with the cases presented in Table 2. Causality assessments tools used to evaluate the cases were not consistent across publications. In order

Table 2. Retrospective cases previously determined to have been caused by consumption of dietary supplements with reported positive reexposure test [2].

\begin{tabular}{|c|c|c|c|c|}
\hline Patient & Reported vent & $\begin{array}{l}\text { Originally } \\
\text { determined } \\
\text { DS causality }\end{array}$ & $\begin{array}{l}\text { Risk factors for } \\
\text { hepatotoxicity not considered } \\
\text { in original evaluation }\end{array}$ & $\begin{array}{l}\text { DS causality } \\
\text { determined on } \\
\text { reevaluation }\end{array}$ \\
\hline $\begin{array}{c}55 \mathrm{yr} \\
\text { female [20] }\end{array}$ & $\begin{array}{l}\text { DS consumption of unknown } \\
\text { daily dose for } 6 \text { months } \\
\text { prior to symptom onset }\end{array}$ & WHO: Certain & $\begin{array}{l}\text { BMI of 33, use of aspirin, } \\
\text { preexisting hyperlipidemia }\end{array}$ & $\begin{array}{l}\text { RUCAM: } \\
\text { Unlikely }\end{array}$ \\
\hline $\begin{array}{c}48 \text { yr } \\
\text { female [20] }\end{array}$ & $\begin{array}{l}\text { DS consumption of unknown } \\
\text { daily dose for } 9 \text { months } \\
\text { prior to symptom onset }\end{array}$ & WHO: Certain & $\begin{array}{l}\text { BMI of 32, use of alpha } \\
\text { adrenergic blocker for } \\
\text { preexisting hypertension }\end{array}$ & $\begin{array}{l}\text { RUCAM: } \\
\text { Unlikely }\end{array}$ \\
\hline $\begin{array}{c}78 \text { yr } \\
\text { female [20] }\end{array}$ & $\begin{array}{l}\text { DS consumption of unknown } \\
\text { daily dose for } 12 \text { months } \\
\text { prior to symptom onset }\end{array}$ & WHO: Certain & $\begin{array}{l}\text { BMI of 27, use of aspirin, } \\
\text { bisphosphonates, preexisting } \\
\text { diabetes mellitus type II }\end{array}$ & $\begin{array}{l}\text { RUCAM: } \\
\text { Unlikely }\end{array}$ \\
\hline $\begin{array}{c}30 \mathrm{yr} \\
\text { male [23] }\end{array}$ & $\begin{array}{l}\text { DS consumption of unknown } \\
\text { daily dose for } 26 \text { months } \\
\text { prior to symptom onset }\end{array}$ & WHO: Certain & $\begin{array}{c}\text { BMI of 33, } \\
\text { preexisting Hepatitis E }\end{array}$ & $\begin{array}{l}\text { RUCAM: } \\
\text { Excluded }\end{array}$ \\
\hline $\begin{array}{c}44 \mathrm{yr} \\
\text { female [21] }\end{array}$ & $\begin{array}{l}\text { DS consumption of unknown } \\
\text { daily dose for } 6 \text { months } \\
\text { prior to symptom onset }\end{array}$ & $\begin{array}{l}\text { WHO: certain } \\
\text { RUCAM: Likely }\end{array}$ & $\begin{array}{l}\text { BMI unknown, use of bupropion for } \\
20 \text { days reported. Case determined } \\
\text { to be poorly documented. }\end{array}$ & $\begin{array}{l}\text { RUCAM: } \\
\text { Excluded }\end{array}$ \\
\hline $\begin{array}{c}39 \mathrm{yr} \\
\text { female [22] }\end{array}$ & $\begin{array}{l}\text { DS consumption of unknown } \\
\text { daily dose for } 6 \text { months } \\
\text { prior to symptom onset }\end{array}$ & $\begin{array}{l}\text { Karch and } \\
\text { Lasagna: } \\
\text { Definite }\end{array}$ & $\begin{array}{l}\text { BMI unknown, viral serology and } \\
\text { imaging results not reported. Case } \\
\text { determined to be poorly documented }\end{array}$ & $\begin{array}{l}\text { RUCAM: } \\
\text { Unlikely }\end{array}$ \\
\hline $\begin{array}{c}49 \mathrm{yr} \\
\text { female [22] }\end{array}$ & $\begin{array}{l}\text { DS consumption of unknown } \\
\text { daily dose for } 2 \text { years } \\
\text { prior to symptom onset }\end{array}$ & $\begin{array}{l}\text { Karch and } \\
\text { Lasagna: } \\
\text { Conditional }\end{array}$ & $\begin{array}{l}\text { BMI unknown, negative virology } \\
\text { reported but no details provided, } \\
\text { case determined to be poorly documented }\end{array}$ & $\begin{array}{l}\text { RUCAM: } \\
\text { Excluded }\end{array}$ \\
\hline
\end{tabular}


to ensure more consistent and standardized evaluation of suspected DILI/HILI it is recommended case reports utilize a structured reporting format like RUCAM. A recent publication reveals: "The [RUCAM] scale is specific and validated for hepatotoxicity, which is not the case for the Naranjo scale, the WHO global introspection method or the ad hoc approach. As these approaches are not specific, and not validated for causality assessment of hepatotoxicity, the author consider them obsolete" [4]. Thus, use of the RUCAM causality assessment tool is currently the only way to achieve comparability from one case report to the next and avoid erroneous conclusions of a causal relationship between a DS and liver disease. The RUCAM tool should also be modified to specifically include consideration of other risk factors such as BMI, a history of rapid weight loss, and hepatitis E infection.

\section{Conclusion}

In conclusion, in order to fully appreciate a clinical presentation of DILI/HILI and determine the actual cause of liver injury when consumption of DS is reported, it is important to consider a multitude of risk factors which may provide a more plausible explanation for the reported event (e.g. viral infection, obesity, NAFLD, diabetes mellitus type II, etc.) and to utilize a more consistent causality assessment method. This point has been emphasized in the literature "to detail the conditions of exposure to [DS] under assessment for a full understanding of the risks associated with consumption" [4]. Though independent experts are working diligently to advance the discussion related to alternative causes of DILI/HILI, the literature continues to recite the same cases to reiterate potentially biased positions and ignore current more consistent and objective evaluation. This in essence, delays any true progress in establishing sound criteria to determine and address the actual cause(s) of DILI/HILI.

\section{References}

[1] Teschke, R., Wolff, A., Frenzel, C., Schulze, J. and Eickhoff, A. (2012) Herbal Hepatotoxicity: A Tabular Compilation of Reported Cases. Liver International, 32, 1543-1556. http://dx.doi.org/10.1111/j.1478-3231.2012.02864.x

[2] Teschke, R., Frenzel, C., Schulze, J., Schwarzenboeck, A. and Eickhoff, A. (2013) Herbalife Hepatotoxicity: Evaluation of Cases with Positive Reexposure Tests. World Journal of Hepatology, 5, 353-363. http://dx.doi.org/10.4254/wjh.v5.i7.353

[3] Teschke, R., Schulze, J., Schwarzenboeck, A., Eickhoff, A. and Frenzel, C. (2013) Herbal Hepatotoxicity: Suspected Cases Assessed for Alternative Causes. European Journal of Gastroenterology \& Hepatology, 25, 1093-1098. http://dx.doi.org/10.1097/MEG.0b013e3283603e89

[4] Zambrone, F.A., Corrêa, C.L. and Amaral, L.M. (2015) A Critical Analysis of the Hepatotoxicity Cases Described in the Literature Related to Herbalife ${ }^{\circledR}$ Products. Brazilian Journal of Pharmaceutical Sciences, 51, 785-796. http://dx.doi.org/10.1590/S1984-82502015000400004

[5] Anderson, J.W. and Konz, E.C. (2001) Obesity and Disease Management: Effects of Weight Loss on Comorbid Conditions. Obesity Research, 9, 326S-334S. http://dx.doi.org/10.1038/oby.2001.138

[6] Chalasani, N., Younossi, Z., Lavine, J.E., Diehl, A.M., Brunt, E.M., Cusi, K., Charlton, M. and Sanyal, A.J. (2012) The Diagnosis and Management of Non-Alcoholic Fatty Liver Disease: Practice Guideline by the American Association for the Study of Liver Diseases, American College of Gastroenterology, and the American Gastroenterological Association. Hepatology, 55, 2005-2023. http://dx.doi.org/10.1002/hep.25762

[7] Promrat, K., Kleiner, D.E., Niemeier, H.M., Jackvony, E., Kearns, M., Wands, J.R., Fava, J.L. and Wing, R.R. (2001) Randomized Controlled Trial Testing the Effects of Weight Loss on Nonalcoholic Steatohepatitis. Hepatology, 51, 121129. http://dx.doi.org/10.1002/hep.23276

[8] Schaffer, J.E. (2003) Lipotoxicity: When Tissues Overeat. Current Opinion in Lipidology, 14, 281-287. http://dx.doi.org/10.1097/00041433-200306000-00008

[9] Brookheart, R.T., Michel, C.I. and Schaffer, J.E. (2009) As a Matter of Fat. Cell Metabolism, 10, 9-12. http://dx.doi.org/10.1016/j.cmet.2009.03.011

[10] Neuschwander-Tetri, B.A. (2010) Hepatic Lipotoxicity and the Pathogenesis of Nonalcoholic Steatohepatitis: The Central Role of Nontriglyceride Fatty Acid Metabolites. Hepatology, 52, 774-788. http://dx.doi.org/10.1002/hep.23719

[11] Caprai, S., Vajro, P., Ventura, A., Sciveres, M. and Maggiore, G. (2008) SIGENP Study Group for Autoimmune Liver Disorders in Celiac Disease. Autoimmune Liver Disease Associated with Celiac Disease in Childhood: A Multicenter Study. Clinical Gastroenterology and Hepatology, 6, 803-806. http://dx.doi.org/10.1016/j.cgh.2007.12.002

[12] Villalta, D., Girolami, D., Bidoli, E., Bizzaro, N., Tampoia, M., Liguori, M., Pradella, M., Tonutti, E. and Tozzoli, R. (2005) High Prevalence of Celiac Disease in Autoimmune Hepatitis Detected by Anti-Tissue Tranglutaminase Autoan- 
tibodies. Journal of Clinical Laboratory Analysis, 19, 6-10. http://dx.doi.org/10.1002/jcla.20047

[13] Volta, U. (2009) Pathogenesis and Clinical Significance of Liver Injury in Celiac Disease. Clinical Reviews in Allergy \& Immunology, 36, 62-70. http://dx.doi.org/10.1007/s12016-008-8086-X

[14] Guturu, P. and Duchini, A. (2012) Etiopathogenesis of Nonalcoholic Steatohepatitis: Role of Obesity, Insulin Resistance and Mechanisms of Hepatotoxicity. International Journal of Hepatology, 2012, 8 p.

[15] Villanova, N., Moscatiello, S., Ramilli, S., Bugianesi, E., Magalotti, D., Vanni, E., Zoli, M. and Marchesini, G. (2005) Endothelial Dysfunction and Cardiovascular Risk Profile in Nonalcoholic Fatty Liver Disease. Hepatology, 42, 473480. http://dx.doi.org/10.1002/hep.20781

[16] Tarantino, G., Conca, P., Basile, V., Gentile, A., Capone, D., Polichetti, G. and Leo, E. (2007) A Prospective Study of Acute Drug-Induced Liver Injury in Patients Suffering from Non-Alcoholic Fatty Liver Disease. Hepatology Research, 37, 410-415. http://dx.doi.org/10.1111/j.1872-034X.2007.00072.x

[17] Dalton, H.R., Fellows, H.J., Stableforth, W., Joseph, M., Thurairajah, P.H., Warshow, U., Hazeldine, S., Remnarace, R., Ijaz, S., Hussaini, S.H. and Bendall, R.P. (2007) The Role of Hepatitis E Virus Testing in Drug-Induced Liver Injury. Alimentary Pharmacology \& Therapeutics, 26, 1429-1435. http://dx.doi.org/10.1111/j.1365-2036.2007.03504.X

[18] Davern, T.J., Chalasani, N., Fontana, R.J., Hayashi, P.H., Protiva, P., Kleiner, D.E., Engle, R.E., Nguyen, H., Emerson, S.U., Purcell, R.H., Tillmann, H.L., et al. (2011) Acute Hepatitis E Infection Accounts for Some Cases of Suspected Drug-Induced Liver Injury. Gastroenterology, 141, 1665-1672.e9. http://dx.doi.org/10.1053/j.gastro.2011.07.051

[19] Kaplowitz, N. (2004) Drug-Induced Liver Injury. Clinical Infectious Diseases, 38, S44-S48. http://dx.doi.org/10.1086/381446

[20] Elinav, E., Pinsker, G., Safadi, R., Pappo, O., Bromberg, M., Anis, E., Keinan-Boker, L., Broide, E., Ackerman, Z., Kaluski, D.N. and Lev, B. (2007) Association between Consumption of Herbalife ${ }^{\circledR}$ Nutritional Supplements and Acute Hepatotoxicity. Journal of Hepatology, 47, 514-520. http://dx.doi.org/10.1016/j.jhep.2007.06.016

[21] Johannsson, M., Ormarsdottir, S. and Olafsson, S. (2010) Hepatotoxicity Associated with the Use of Herbalife. Laeknabladid, 96, 167-172.

[22] Manso, G., López-Rivas, L., Salgueiro, M.E., Duque, J.M., Jimeno, F.J., Andrade, R.J. and Lucena, M.I. (2011) Continuous Reporting of New Cases in Spain Supports the Relationship between Herbalife ${ }^{\circledR}$ Products and Liver Injury. Pharmacoepidemiology and Drug Safety, 20, 1080-1087. http://dx.doi.org/10.1002/pds.2180

[23] Schoepfer, A.M., Engel, A., Fattinger, K., Marbet, U.A., Criblez, D., Reichen, J., Zimmermann, A. and Oneta, C.M. (2007) Herbal Does Not Mean Innocuous: Ten Cases of Severe Hepatotoxicity Associated with Dietary Supplements from Herbalife ${ }^{\circledR}$ Products. Journal of Hepatology, 47, 521-526. http://dx.doi.org/10.1016/j.jhep.2007.06.014 